\title{
Aratrocypris, an enigmatic new cyprid ostracod from the Tertiary of D.S.D.P. sites in the S.W. Pacific
}

\author{
${ }^{1}$ ROBIN WHATLEY, ${ }^{1}$ MICHAEL AYRESS, ${ }^{1}$ SIAN DOWNING, ${ }^{2}$ CHRISTOPHER HARLOW \& ${ }^{1} \mathrm{KARIN}$ KESLER \\ ${ }^{1}$ Micropalaeontology Division, Department of Geology, University College of Wales, Aberystwyth, U.K. \\ ${ }^{2}$ Gearhart Geodata Services Ltd., Dyce, Aberdeen
}

\begin{abstract}
The new cyprid genus, Aratrocypris, based on four species ranging in age from Upper Palaeocene to Recent, is described. One species is left in open nomenclature and three, A.rectoporrecta (the type species), A.vaccamaris and $A$.praealta are described as new. The genus bears a unique plough-like structure anteroventrally and the possible function of this and the palaeoecology of the animal are discussed in detail. It is suggested that the plough-like structure, in association with other carapace structures such as the posterior position of the adductor muscle scars and the hinge, together with the strong degree of anterodorsal overlap, are indicators of a feeding mode associated with forward movement through the sediment. However, it is also possible that the animal was a filter feeder living within the sediment at a steep angle to the sea floor with the anteroventral structure protruded beyond the sediment water interface.
\end{abstract}

\section{INTRODUCTION}

During the course of our studies of Tertiary Ostracoda from D.S.D.P. sites in the S.W. Pacific, we have encountered numerous new species and a number of new genera. Among the latter is the new cypridacean genus Aratrocypris which is the subject of this paper.

Maddocks (1969) described a cyprid ostracod bearing a "flange-like projection" anteriorly as Australoecia sp. 1. She also commented on the "ventral position and honeycomb-texture arrangement of the muscle scars". Her single specimen, from the sub-Recent of the eastern Pacific (lat. $26^{\circ} 30^{\prime} \mathrm{S}$; long. $105^{\circ} 45^{\prime} \mathrm{W}$ ) and at $2089 \mathrm{~m}$, does not conform to the genus Australoecia McKenzie, 1967 nor to Maddocksella McKenzie, 1983, to which some species hitherto referred to Australoecia have recently been reassigned. Australoecia sp. 1 Maddocks, 1969 clearly belongs to Aratrocypris and probably is conspecific with $A$.rectoporrecta sp.nov.

Aratrocypris gen. nov., so named because of its characteristic plough-like anteroventral projection, is a consistent, if somewhat uncommon, component of Tertiary deep sea faunas from D.S.D.P. sites in the S.W. Pacific. The genus is represented by four species, all from the Pacific. A further species has recently been recorded from deep water in the N.W. Atlantic (as Argilloecia sp. B) by Cronin (1983). Benson (lit.comm., June 1983) has not encountered this genus in his considerable experience of D.S.D.P. studies in the world's oceans. Steineck (lit.comm., July 1983) in his studies on Tertiary Ostracoda from the Central Pacific has similarly failed to encounter the genus.
In our material, the genus ranges from the Upper Palaeocene, Teurian stage, through to the Pleistocene and is found fairly consistently in the Eocene, Miocene, Pliocene and Pleistocene but, as yet, has not been encountered in the Oligocene.

\section{SYSTEMATIC DESCRIPTIONS}

Order Podocopida Müller, 1894

Superfamily Cypridacea Baird, 1845

Family Pontocyprididae Müller, 1894

Genus Aratrocypris gen. nov.

Type species. Aratrocypris rectoporrecta gen. et sp. nov. Derivation of name. Latin, from the plough-like nature of the anterior extremity of this genus.

Diagnosis. A small weakly calcified cypridacean genus with right valve markedly larger than left and pronounced anterodorsal overlap. Lateral outline subtriangular to sub-ovate. Subacuminate anteriorly with anteroventral margin produced into a broad, laterally compressed plough-like structure immediately posteroventral of which is an inverted ' $V$ '-shaped incurvature; this structure may or may not gape ventrally.

Dorsal margin arched to sub-umbonate with apex posterior of mid-length. Ventral margin straight to gently convex with little or no trace of oral incurvature in either valve. Posterior margin rounded to subtruncated. Posteroventral angle of left valve with blunt spine in most species. Sub-pyriform in dorsal view with gentle taper towards anterior from area of greatest width in posterior third of carapace. Inner lamella delicate and weakly calcified; very wide anteriorly in some species. 
Vestibulae; wide anteriorly, semi-circular, sub-triangular or sub-rectangular; narrow and crescentic or triangular posteriorly. Adductor muscle scars consisting of five sub-triangular to sub-rectangular scars in a compact rosette, situated behind mid-length and at or slightly below mid-height. Hinge adont, short, very posteriorly situated and at a steep angle to the horizontal.

Remarks. Aratrocypris differs from all other known Ostracoda in possessing a plough-like anterior extremity and associated inverted ' $V$ '-shaped incurvature. The muscle scar pattern resembles that of some species of Argilloecia and both Australoecia and Maddocksella. Probably Aratrocypris shared a common early Palaeocene or late Cretaceous ancestry with the latter two genera.

While most common at bathyal palaeodepths, it also occurs in the abyss. From the Miocene onwards, the genus is not recorded at depths of less than $1000 \mathrm{~m}$. However, the Palaeocene and Eocene representatives in this study are thought, by virtue of their association with such genera as Cytherelloidea Alexander and sighted species, to have lived in somewhat shallower water.

Type and figured specimens are deposited in the collections of the Dept. of Palaeontology of the British Museum (Natural History) and the OS catalogue numbers apply to these. Other figured specimens are deposited in the collections of the Micropalaeontology Museum, U.C.W., Aberyswyth. These have the numbers prefixed $\mathrm{UCW} / \mathrm{O}$.

\section{Aratrocypris rectoporrecta sp. nov.}

(Pl. 1, figs. 1-18, Fig. 1)

?1969 Australoecia sp. 1 Maddocks p. 50, fig. 35a, j. Derivation of name. Latin, from the considerable degree by which the right valve overlaps the left in this species. Diagnosis. A relatively large, strongly arched dorsally and subumbonate species of Aratrocyris with a very well developed anteroventral plough-like structure which gapes ventrally and which, particularly in the left valve, makes a marked angle with the anterior margin; anteroventral incurvature strongly developed. Posterior margin truncated and in left valve bearing a short posteroventral spine. Right valve strongly overlapping left. Surface smooth. Internal features as for genus.

Holotype. Left valve, OS12227.

Material. 29 specimens: 10 adults, 19 juveniles. Locality and horizon. D.S.D.P. Site 209, Queensland Plateau, lat. $15^{\circ} 56.19^{\prime} \mathrm{S}$.; long $152^{\circ} 11.27^{\prime} \mathrm{E}$. Core 1 , section 5 , interval $75-80 \mathrm{cms} ; 6 \mathrm{~m}$ below sea floor. Late Middle-Upper Pleistocene, nannofossil bearing foraminiferal calcic ooze. Planktonic foraminiferal zone N22 of Blow (1969).
Description. Medium sized, delicately calcified. Subtriangular to sub-ovate in lateral view. Drop-shaped in dorsal view tapering from greatest width in the posterior $1 / 4$ to the anterior; posterior $1 / 4$ well rounded. Anterior margin strongly tapering and bearing, at the anteroventral extremity, a large and well developed ploughlike flange which, in the left valve, forms a marked angle with the anterodorsal slope of the anterior margin. Immediately posteroventral of this structure is a welldeveloped inverted ' $V$ '-shaped incurvature. Posterior margin truncated, particularly in left valve which bears a short blunt spine at the posteroventral angle. Dorsal margin a high asymmetrical arch with sub-umbonate apex behind mid-length. Ventral margin straight. Surface smooth. Normal pore canals few, small and open with lips. Inner lamella moderately wide anteriorly and posteriorly; narrow ventrally. Anterior vestibulum wide; posterior narrower and triangular. Radial pore canals concentrated anteriorly where approximately six straight canals extend to the periphery of the anterior plough-like structure. False radial pore canals occur anteriorly, ventrally and posteriorly. Muscle scars consist of a compact rosette of five sub-triangular adductors, comprising a lower arcuate row of three scars surmounted by two larger scars; situated behind midpoint and at or below mid-height. Hinge adont, short, extending from the apex of the dorsal margin to the posterior cardinal angle and at a steep angle to the horizontal.

$\begin{array}{lcc}\begin{array}{l}\text { Dimensions (mm) } \\ \text { Holotype, }\end{array} & \text { Length } & \text { Height } \\ \begin{array}{l}\text { LV, OS12227-209/1/5, M.Pleistocene } \\ \text { Paratype, }\end{array} & 0.56 & 0.30 \\ \begin{array}{l}\text { car., OS12228-209/6/1, Miocene } \\ \text { Paratype, }\end{array} & 0.45 & 0.25 \\ \begin{array}{l}\text { LV, OS12229-208/7/5, Pliocene } \\ \begin{array}{l}\text { Paratype, } \\ \text { LV, OS12230-207A/20/3, M. Eocene }\end{array}\end{array} & 0.41 & 0.23 \\ \begin{array}{l}\text { Paratype, } \\ \text { RV, OS12231-209/1/1, U. Pleistocene }\end{array} & 051 & 0.27 \\ \end{array}$

Remarks. This species is distinguished by its more angular and better developed anterior plough-like structure; by its more truncated posterior margin and by the very strong overlap of the left valve by the right. The single specimen described by Maddocks (1969) from the sub-Recent of the Eastern Pacific (lat. 26 30'S, long. 105 $45^{\prime} \mathrm{W}$ ) at $2089 \mathrm{~m}$, as Australoecia sp. 1, is tentatively included within this species. In some specimens of this species, abrasion of the ventral surface of the "plough" is responsible for the appearance of a dentate appearance (Pl. 1, fig. 7).

Distribution. The species ranges from the Middle Eocene to the Recent and details of its occurrence are given below: 


\begin{tabular}{|c|c|c|c|c|c|}
\hline Site & $\begin{array}{c}\text { Water } \\
\text { Depth (m) }\end{array}$ & Core & Section & $\begin{array}{c}\text { Interval } \\
\text { (cm) }\end{array}$ & Age \\
\hline 209 & 1428 & 1 & 1 & $75-80$ & U.Pleistocene \\
\hline 209 & 1428 & 1 & 5 & $75-80$ & M.Pleistocene \\
\hline 209 & 1428 & 2 & 2 & $75-80$ & M.Pleistocene \\
\hline 209 & 1428 & 2 & 6 & $75-80$ & L.Pleistocene \\
\hline 209 & 1428 & 4 & 4 & $6-16$ & Pliocene \\
\hline 208 & 1545 & 4 & 4 & $7-18$ & Pliocene \\
\hline 208 & 1545 & 5 & 6 & $7-18$ & Pliocene \\
\hline 208 & 1545 & 7 & 5 & $15-25$ & Pliocene \\
\hline 208 & 1545 & 9 & 5 & $6-17$ & Pliocene \\
\hline 209 & 1428 & 6 & 1 & $90-95$ & Miocene \\
\hline 207A & 1389 & 9 & 4 & $20-25$ & Miocene \\
\hline 207A & 1389 & 11 & 4 & $85-90$ & M.Eocene \\
\hline 207A & 1389 & 20 & 3 & $85-90$ & M.Eocene \\
\hline
\end{tabular}

Aratrocypris vaccamaris sp. nov.

(Pl. 2, figs. 1-7)

Derivation of name. Latin, seacow. From the superficial overall resemblance of this species to a manatee or dugong.

Diagnosis. A small relatively elongate species of Aratrocypris. Anteroventral plough-like structure subcrescentic, anteroventral ' $V$ '-shaped incurvature rather shallow, no ventral gape. Dorsal margin umbonate, apex behind mid-length. Anterolateral surface with weak ornament of low broad ridges which sub-parallel the margins. Inner lamella very wide anteriorly. Posteroventral spine not developed in right valve.

Holotype. Carapace, OS12232.

Material. 154 specimens: 42 adult valves, 112 juveniles. Locality and horizon. D.S.D.P. Site 200, Ita Mai Tai Guyot, lat. $12^{\circ} 50.2^{\prime} \mathrm{n}$, long. $156^{\circ} 47^{\prime} \mathrm{E}$. Core 9 , section 3 , interval $90-95 \mathrm{cms} ; 89.4 \mathrm{~m}$ below sea floor. Middle Miocene, planktonic foraminiferal zone N8 of Blow (1969). Calcareous nannofossil zone of Sphenolithus heteromorphis Bukry (1973) and Threrstein (1971). Unconsolidated, pale grey nannofossil bearing foraminiferal ooze. Present day water depth $1469 \mathrm{~m}$.

Description. Small, sub-ovate in lateral outline. Narrowly sub-pyriform in dorsal view. Anterior narrow with anteroventral sub-crescentic plough-like structure produced anteroventrally which is sub-denticulate peripherally; posteroventral of this a very shallow inverted ' $V$ '-shaped incurvature is developed. Posterior margin bluntly rounded. Dorsal margin with long gently convex anterior and shorter almost straight posterior slopes on either side of a distinct umbonate apex behind mid-length. Ventral margin almost straight in right valve; with very weak incurvature in left. Greatest length below mid-height; Greatest height and width behind mid-length. Right valve larger than left with midventral and anterodorsal overlap, the latter being particularly strong. Anterolateral surface with a series of weak low ridges which parallel the margins; remainder of valve smooth. Inner lamella delicately calcified, very wide anteriorly with sub-rectangular anterior vestibulum. Radial pore canals not seen. Adductor scars in a compact rosette of five sub-ovate scars situated behind mid-length and at, or just below, mid-height. Hinge adont, extending from dorsal apex to posterodorsal angle and steeply inclined to the horizontal.

Dimensions (mm). All from D.S.D.P. Site 200, core 9, section 3, level $90-95 \mathrm{cms}$. Miocene in age.

Holotype, car., OS12232

Length Height

Paratype, LV, OS12233

$0.43 \quad 0.22$

Paratype, LV, OS12234

$0.41 \quad 0.22$

Paratype, RV, OS12235

$0.44 \quad 0.21$

$0.43 \quad 0.23$

Remarks. Aratrocypris vaccamaris differs from the three other known species of the genus in its more elongate outline, anterolateral ornament and in the absence of a posteroventral spine in the right valve.

Distribution. The species is apparently restricted to the Miocene of Site 200 of the Ita Mai Tai Guyot and has been found in the single sample 200/9/3. It seems to have evolved on the guyot at bathyal depths (P.D.W.D. $1469 \mathrm{~m}$ ) in isolation surrounded by abyssal depths of some $6000 \mathrm{~m}$.

\section{Aratrocypris praealta sp. nov.}

(Pl. 2, figs. 8-13)

Derivation of name. Latin, from the very high carapace of this species.

Diagnosis. A relatively large and tumid species with well rounded sub-ovate to sub-triangular outline in lateral view. Anteroventral plough-like structure only moderately developed and with ventral gape. Dorsal margin arcuate with rounded apex posterior of mid-length. Posterior margin rounded in left valve with blunt posteroventral spine.

Holotype. Left Valve, OS12236.

Material. 25 specimens: 14 adults, 11 juveniles. Locality and horizon. D.S.D.P. Site 56, Caroline Ridge, lat. $8^{\circ} 22.4^{\prime} \mathrm{N}$; long. $143^{\circ} 33.6^{\prime} \mathrm{E}$. P.D.W.D. $2508 \mathrm{~m}$. Hole 2, Core 5 , section 2, interval $90-95 \mathrm{~cm}$. Middle Miocene. Nannofossil bearing foraminiferal chalk ooze, $G$. fohsi zone.

Description. Relatively large for the genus. Sub-ovate to sub-triangular in lateral view; sub-elliptical and tumid in dorsal view. Anterior margin a gently convex slope tapering towards a plough-like anteroventral structure, posteroventral of which is a ' $V$ '-shaped incurvature, better developed in the right than the left valve. Posterior margin rounded in right valve and bearing a blunt spine posteroventrally; more pointed in left valve. Dorsal margin a high asymmetrical arch with rounded apex behind mid-height. Ventral margin straight with slight median concavity in left valve; gently convex in right. Right valve larger than left with strong anterodorsal overlap. Smooth. Internal features as for genus. 
Dimensions (mm)

Holotype,

LV, OS12236-56.2/5/2, Miocene

Paratype,

RV, OS12237-56.2/5/4, Miocene

Length Height

Paratype,

RV, OS12238-207A/11/4, M. Eocene $0.45 \quad 0.27$

Paratype,

car., OS12239-207A/11/4, M. Eocene $0.36 \quad 0.21$

Paratype,

car., OS12240-277/43/2, L. Eocene $\quad 0.37 \quad 0.21$

Remarks. Aratrocypris praealta sp.nov. is clearly distinguished by its high non-umbonate arched dorsal margin and by its more tumid outline in dorsal view. It most closely resembles $A$.rectoporrecta sp.nov. but that species has a more umbonate apex to the dorsal margin, a truncated posterior margin and is much less tumid in dorsal view.

Distribution. This species ranges from the Upper Palaeocene to the Miocene and details of its occurrence are given below:

Site Water Core Section Interval Age Depth (m)

$56.22850 \quad 5 \quad 2 \quad 90-95$ Miocene

$56.2 \quad 2850 \quad 5 \quad 4 \quad 90-95$ Miocene

207A $1389 \quad 11 \quad 4 \quad 85$ - 90 M.Eocene

$\begin{array}{lllll}277 & 1214 & 43 & 2 & 40-46 \\ & \text { L.Eocene }\end{array}$

207A $1389 \quad 26 \quad 4 \quad 135-140$ U.Palaeocene

The species inhabited bathyal waters in the Palaeogene but was apparently confined to abyssal depths in the Miocene.

Aratrocypris sp.

(Pl. 2, figs. 11-17)

Material. 6 specimens: 2 adult carapaces, 4 juvenile valves.

Diagnosis. A small sub-ovate to sub-triangular species characterised by a short straight hinge margin in the left valve. Surface smooth. Maximum width posterior of midpoint, tapering anteriorly. Posteroventral spine not developed in left valve. Internal features as for genus.

Dimensions (mm)

RV, OS12241-209/1/1,

U.Pleistocene

car., OS12243-209/27/2,

M.Eocene

car., OS12242-209/27/2,

M.Eocene

Remarks. This species is left in open nomenclature due to paucity of material. It is clearly distinguished from the other three known members of this genus by the short straight hinge margin in the right valve and in its rounded posterior margin.

Distribution. The species has been recovered from the Lower and Middle Eocene and from the uppermost Pleistocene.

Site Water Core Section Interval Age

Depth $(\mathrm{m}) \quad(\mathrm{cm})$

$\begin{array}{llllll}209 & 1428 & 1 & 1 & 75-80 & \text { U.Pleistocene }\end{array}$

$\begin{array}{llllll}209 & 1428 & 27 & 2 & 83-88 & \text { M.Eocene }\end{array}$

$\begin{array}{llllll}209 & 1428 & 27 & 2 & 83-88 & \text { M.Eocene }\end{array}$

\section{Explanation of Plate 1}

All figures are $\times 100$ unless otherwise stated.

Aratrocypris rectoporrecta gen. et sp. nov.

Figs. 1-3, 9 \& 10. Holotype LV, OS12227, Middle Pleistocene, Site 209, core 1, section 5: fig. 1, int; fig. 2, dors.; fig. 3, vent.; fig. 9, ant.; fig. 10, oblique ant.-vent.

Figs. 4, 5. Paratype LV, A-1 juv. OS12229, Pliocene, Site 208, core 7, section 5; fig. 4, ext. lat; fig. 5, int.

Figs. 6, 14, 15. Paratype car., OS12228, Miocene, Site 209, core 6, section 1; fig. 6, left ext. lat; fig. 14, dors; fig. 15, vent.

Fig. 7. Paratype RV, A-1 juv., OS12231, Upper Pleistocene, Site 209, core 1, section 1, ext. lat.

Fig. 8. A-2 juv., LV UCW/0/1001, Middle Eocene, Site 207A, core 20, section 3, ant.

Fig. 11. LV, UCW/0/1002, Middle Eocene, Site 207A, core 20, section 3, ext. lat.

Fig. 12. LV, UCW/0/1003, Pliocene, Site 208, core 4, section 4, ext. lat.

Fig. 13. LV, UCW/0/1004, Middle Eocene, Site 207A, core 20, section 3, ext. lat.

Fig. 16. LV, UCW/0/1005, Middle Eocene, Site 207A, core 11, section 4, ext. lat.

Fig. 17. LV, UCW/0/1006, Miocene, Site 207A, core 9, section 4, ext. lat.

Fig. 18. A-2 juv., LV, UCW/0/1007, Pliocene, Site 208, core 4, section 4, int.

Fig. 19. A-1 juv., LV, UCW/0/1008, Middle Eocene, Site 207A, core 20, section 3, detail of ventral surface of plough (approx. $\times 1000$ ). 


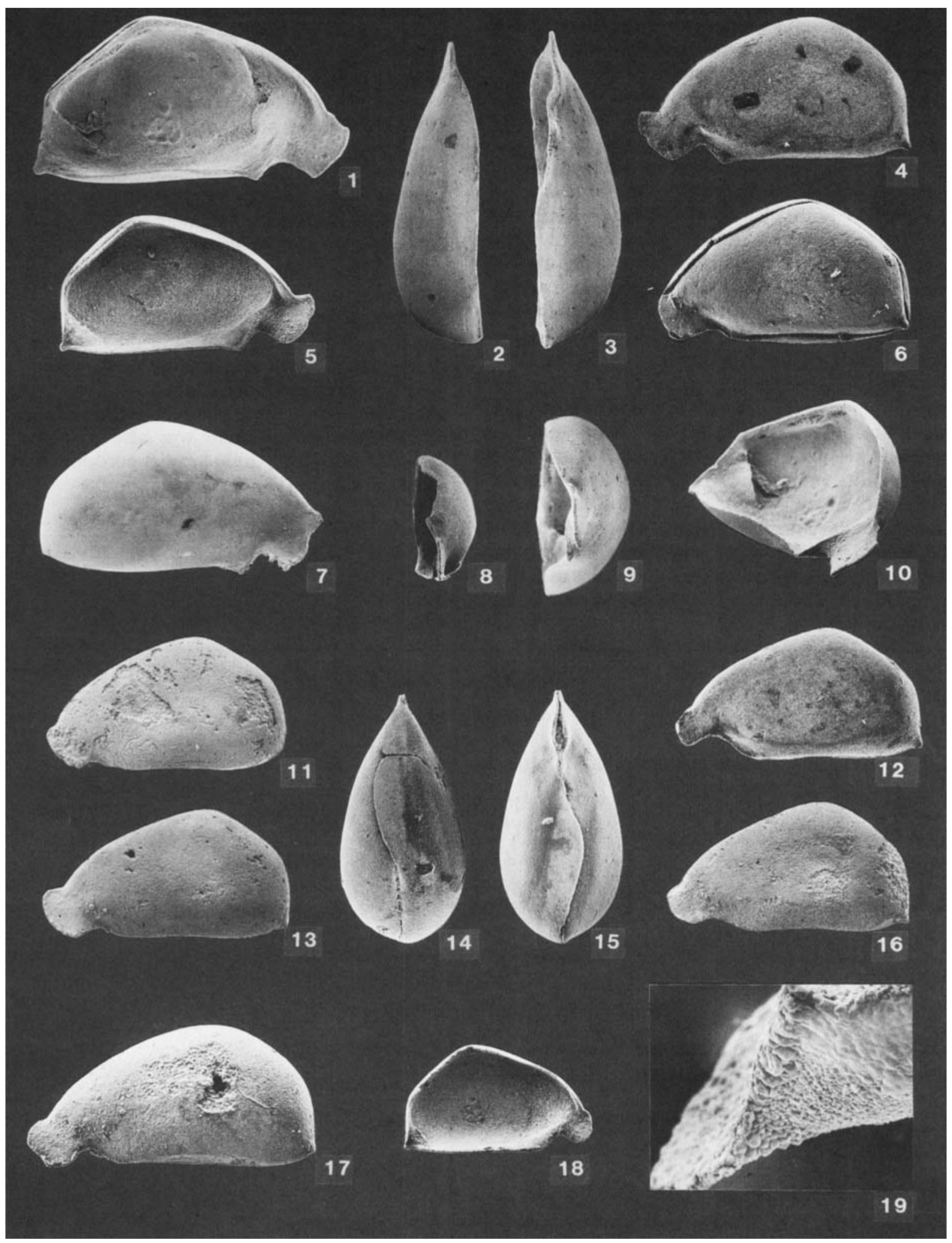




\section{ECOLOGY AND MODE OF LIFE}

The Palaeocene and early Eocene representatives of the genus probably lived in rather shallow water since they occur in association with such well known shallow water genera as Cytherelloidea Alexander, 1929 and species with well developed eyes. Probably in the late Palaeogene the genus began to enter deeper water and at least by the Miocene, Aratrocypris was established in the Pacific as a deep sea ostracod. In the Miocene the genus occurs in both bathyal (1000 to $2000 \mathrm{~m}$ ) and abyssal $(2000 \mathrm{~m})$ environments. We believe that Aratrocypris evolved in the S.W. Pacific/Australasian region during the Palaeocene, probably from a common ancestor which it shared with Australoecia and Maddocksella and which may have been Argilloecia Sars. We suggest also that Aratrocypris entered the deep sea in the same general region and that the mechanism of induction into this environment was by crustal foundering of areas of continental shelf to bathyal depths at a rate slow enough to allow elements of the fauna to adjust and survive. This mechanism has been invoked to explain the importance of the region between Australia and New Zealand as a locus for induction into the deep sea (Whatley, 1983; Whatley et al., 1984). From the inital locus of entry into the deep sea, Aratrocypris has spread at least as far as the eastern Pacific, and has recently been recorded in the N.W. Atlantic (Cronin, 1983).
The anteroventral plough-like structure is unique to the genus. Its exact function is somewhat enigmatic, but is probably associated with the feeding habit of the animal. This structure is present in all four species and is associated with a more or less well developed inverted ' $V$ '-shaped incurvature of the outer margin anteroventrally.

Interpretation of the function of the anteroventral structure rests largely on whether one considers the animal to have been infaunal or epifaunal in habit. However, because of its morphology, it is difficult to avoid the possibly anthropomorphic suggestion that it acted in some way as a plough. A plough-like structure could facilitate forward movement, whether only the structure itself, or all, or most of the animal was within the sediment. Some support for this suggestion that the structure acted as a plough, is provided by the fact that in all species its periphery is somewhat thickened and reinforced. The structure was also provided with a sensorial capability, in that radial pore canals extend to its distal margin (Fig. 1).

\section{Explanation of Plate 2}

All figures are $\times 100$.

Figs. 1-7 Aratrocypris vaccamaris sp. nov. All Miocene, Site 200, core 9, section 3.

Figs. 1, 4. Paratype RV, OS12235, fig. 1, ext. lat. fig. 4, int.

Fig. 2. RV, UCW/0/1009, ext. lat.

Fig. 3, Paratype LV, OS12233, ext. lat.

Figs. 5, 6. Holotype, car, OS12232; fig. 5, dors; fig. 6, vent.

Fig. 7. Paratype LV, OS12234, int.

Figs. 8-13 Aratrocypris praealta sp. nov.

Fig. 8. Holotype LV, OS12236, Miocene, Site 56.2, core 5, section 2, ext. lat.

Fig. 9. RV, UCW/0/1010, Miocene, Site 56.2, core 5, section 4, ext. lat.

Fig. 10. Paratype RV, OS12238, Middle Eocene, Site 207A, core 11, section 4, ext. lat.

Figs. 11, i2. Paratype car, OS12239, Middle Eocene, Site 207A, core 11, section 4, fig. 11 dors; fig. 12, vent.

Fig. 13. LV, UCW/0/1011, Miocene, Site 56.2, core 5, section 2.

Figs. 14-17. Aratrocypris sp.

Fig. 14. car, OS12243, Middle Eocene, Site 209, core 27, section 2, right ext. lat.

Fig. 15. LV, UCW/0/1012, Lower Eocene, Site 207A, core 25, section 4, ext. lat.

Fig. 16. RV, OS12241, Upper Pleistocene, Site 209, core 1, section 1, ext. lat.

Fig. 17. car, OS12242, Middle Eocene, Site 209, core 27, section 2, left ext. lat. 


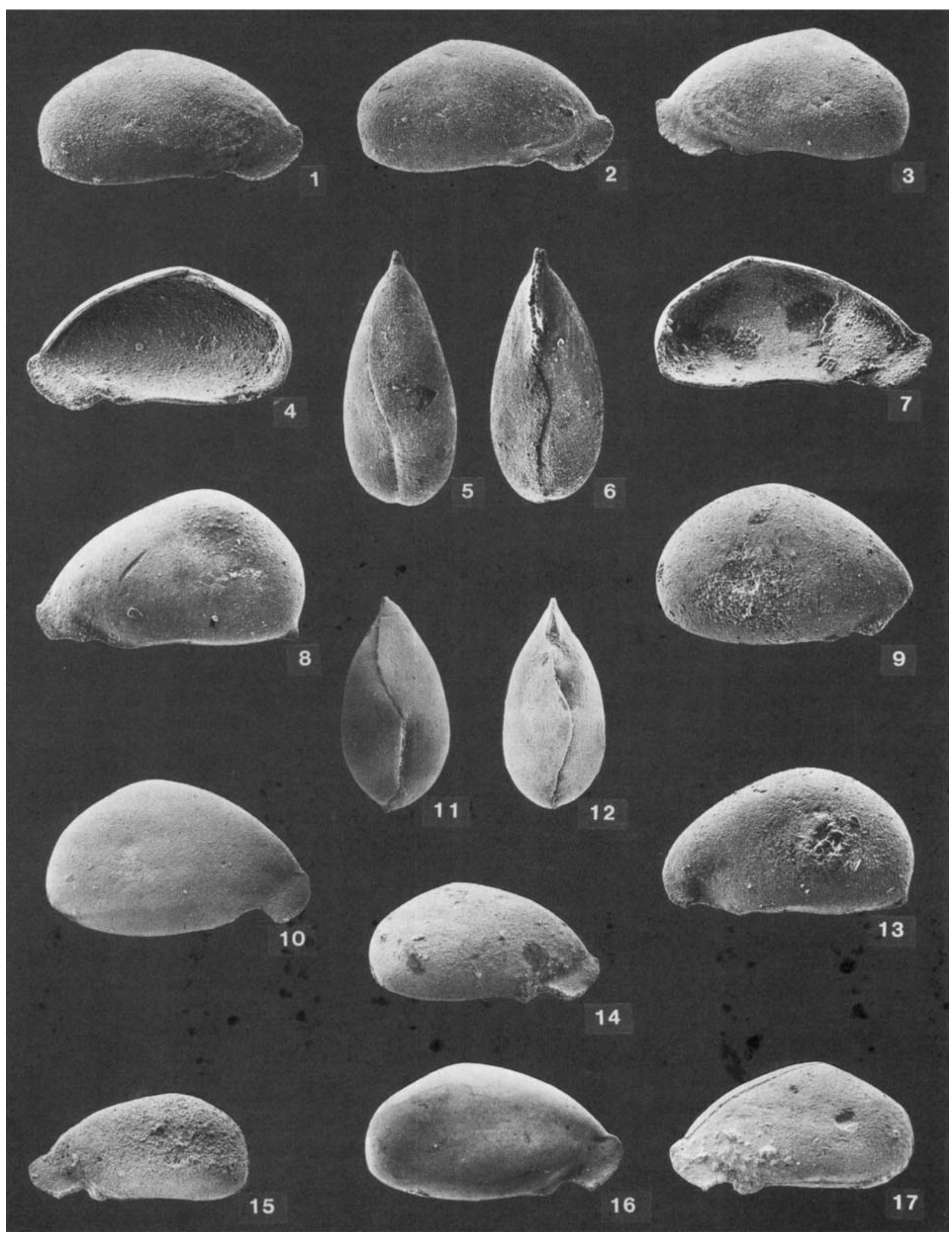




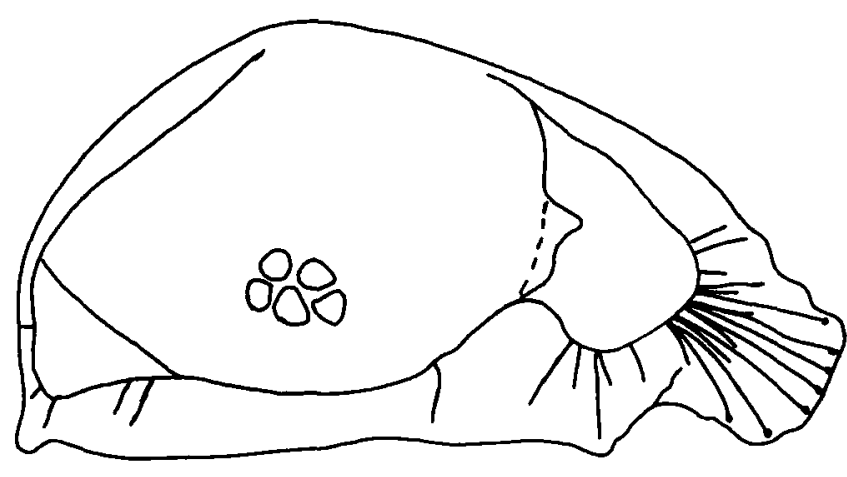

Fig. 1 Aratrocypris rectoporrecta sp. nov. Holotype OS12227 LV. Internal view showing radial pore canals and adductor muscle scars.

The ' $V$ '-shaped incurvature of the anteroventral margin, which occurs immediately behind the ploughlike structure, is almost certainly associated with feeding. While the exact nature of this incurvature is unique to Aratrocypris, occurring as it does immediately posterior to the "plough", somewhat similar incurvatures occur in other cypridacean ostracods. For example, the extinct Jurassic and Cretaceous genus Cypridea sensu lato Bosquet has a more or less well developed "notch" behind its posteroventrally directed "beak". A somewhat similar structure occurs in some Recent South American species of Chlamydotheca Saussure and in the cytherid genus Platymicrocythere Schornikov, 1975. Although the anteroventral incurvature in Cypridea, Chlamydotheca and Platymicrocythere can be generally interpreted as being associated with their feeding habit, no detailed discussion of its function exists which would be of assistance in the interpretation of the feature in Aratrocypris. The only other ostracods with similar structures are certain myodocopids, such as Cypridina Milne-Edwards and Philomedes Liljeborg. However, the rostrum and rostral incisure are, in these genera situated anterodorsally and mid-anteriorly respectively, and are associated with locomotion and cannot be related to the very superficially similar structures in Aratrocypris.

It is perhaps significant that the mid-ventral margin of Aratrocypris exhibits little or nothing of the oral incurvature characteristic of most podocopids and which is generally interpreted as being associated with feeding. The exact function of the ' $V$ '-shaped incurvature is difficult to assess. Possibly it was a device through which unwanted matter could be discharged laterally while food selection and consumption took place within the blades of the plough. If this were the case, the possibility exists that the second antennae were modified to assist in the process of selecting and rejecting particles and in passing favoured items back to the mandibles. Perhaps in association with this, the mouth and mandibles were shifted forward of their normal position in cyprid ostracods.

Another possible function of the incurvatures is that they allowed the posterolateral escape of sediment from between the two blades of the "plough" during forward motion, thus preventing ingress of foreign particles into the carapace.

In considering the mode of life of Aratrocypris, five other morphological features of the genus must be taken into consideration:

1. The right valve is considerably larger than and strongly overlaps the left; the degree of overlap from mid-dorsal to mid-anterior is exceptionally large. This strong anterodorsal overlap is interpreted as a device to allow the animal to open its valves anteroventrally when within the sediment without allowing foreign particles into the carapace. Additionally, the degree of overlap would serve to afford a degree of protection to the anterior appendages.

2 . The hinge is relatively short and is situated very posteriorly: behind mid-point. It is also inclined at a steep angle to the horizontal and is approximately parallel to the leading edge of the "plough". This positioning of the hinge would allow the valves to gape widely anteriorly and possibly, therefore, the two blades of the "plough" gaped when the animal moved forward through the sediment. This would explain the need for increased anterodorsal overlap.

3 . The adductor scars are much more posterior in position than they are in most ostracods. This, despite the mechanical inefficiency associated with moving the muscles nearer to the hinge, is probably related to the need for a wide anterior gape. It is rare for ostracods to have their adductor muscles situated well behind midlength. In Conchoecia Dana, a Recent pelagic myodocopid, the muscle scars are situated posterior of midlength because of its enlarged cephalon. The latter is necessarily large to be able to bear the large locomotory first and second antennae with which this genus swims. Many deep sea species of Eucythere sensu lato Brady, also have posteromedianly situated adductor scars as do many of the as yet undescribed species of the genera, which are clearly related to Aratrocypris, which we have encountered in deep sea Tertiary deposits in the S.W. Pacific. Among these are species of Australoecia McKenzie, 1967,Abyssocypris Bold, 1974 and Maddocksella McKenzie, 1983 and in most instances their adductor muscle scars are situated somewhat posterodorsal of midpoint.

We can only surmise that in all these taxa and Aratrocypris the adductor muscle scars were displaced posteriorly to accommodate an enlarged cephalon. Why in Aratrocypris should the cephalon be enlarged? Usually this phenomenon in Ostracoda is a response to the need to provide attachment for enlarged anterior appendages. 
Although we have no direct evidence that the first and second antennae or the mandibles were enlarged in Aratrocypris, or that the latter appendage was moved forward, if the unique anterior and posterior features of the carapace are modifications associated with a singular feeding habit, then it is not unreasonable to assume a concomitant modification of the appendages.

It is correct, however, to assume that modifications of the appendages would necessarily be solely and directly associated with alimentation? Cyprid ostracods bear only one locomotory appendage on the thorax. If the cephalon of Aratrocypris is enlarged then this must be at the expense of the thorax and a truncated thorax might be expected to bear a second thoracic limb of reduced size and, therefore, reduced locomotory capability. If this is the case, then the locomotory function of the first and second antennae would require to be enhanced. This of course assumes that the anterior carapace structures of Aratrocypris are associated with a feeding habit which requires forward movement through the sediment. If this is the case, and if the thoracic walking leg is reduced, then the first and/or second antennae may have borne strong terminal hooks or claws to pull the animal through the sediment.

No living specimen of the genus has yet been encountered so any discussion of its soft parts must be highly speculative. However, it is virtually inconceivable that such a unique elaboration of the carapace would not be accompanied by complementary modifications of the appendages.

4. We have not encountered sexual dimorphism in any of the four species of Aratrocypris. Allied genera such as Maddocksella, Austaloecia and Argilloecia exhibit sexual dimorphism, at least in most of their species, although in many cases the expression of the dimorphism in carapace characteristics is rather subtle. The apparent absence of sexual dimorphism in aratrocypris may be related to the presumed reduction in size of the thorax. This reduction would not be compatible with the possession of large external genitalia. The genus is thought, therefore, to reproduce parthenogenetically.

5. Except in A. vaccamaris and A. sp., the smaller left valve bears a pronounced spine at the posteroventral angle. In some other ostracods, such as certain members of the cytherid Cytherideinae (e.g. Cyprideis Jones, Galliaecytheridea Oertli, etc.), where one valve is considerably larger than the other, the smaller valve bears a posteroventral spine. This is interpreted as a device to allow such asymmetrical animals to maintain themselves in a perpendicular attitude. The same function is thought to apply to this structure in Aratrocypris.

Fig. 2 illustrates possible life modes of Aratrocypris. The series a. to e. represents a transition from an epifaunal to a completely infaunal existence, with intermediate stages between. This series of reconstructions assumes that the animal lived horizontal to the sediment. The authors consider model a. (and to a large extent model b.) to be the least likely modes of life to adopt if the "plough" is an adaptation to feeding by forward movement through the sediment. Neither a. nor b. would bury the "plough" sufficiently to maximise it in this postulated rôle. Model c. is considered somewhat more favourably in that it covers the last objection. However, model c. would not necessitate the large degree of anterodorsal overlap (thought to be a modification to allow the carapace to gape anteriorly without the ingress of sediment). Models $d$. and e. would, however, require this protective overlap and are, therefore, perhaps more logical reconstructions than models a. to $\mathrm{c}$.

Models f. and g. in Fig. 2 are based on the assumption that the animal lived (or fed) at a slight or steep angle to the horizontal respectively. There could, of course be gradations between these extremes. Model $\mathrm{g}$. is not favoured because, with the carapace at such a steep angle, progress through the sediment would be both difficult and mechanically inefficient. Also, if as suggested above, the thorax and, therefore, the second thoracic appendage is reduced in Aratrocypris, model g. becomes even more implausible. A life or feeding mode reconstruction somewhere between models $f$. and g. does seem fairly satisfactory, although this type of mode would not explain the exaggerated anterodorsal overlap.

In Fig. 2, models a. to g. all assume that the "plough" is a modification associated with forward movement. It is not impossible, however, that this interpretation is erroneous. Models $h$. and $i$. are based upon the possibility that the animal lived with the greater part of its carapace within the sediment in a vertical or near vertical attitude. Such models would imply that the "plough", instead of performing the function attributed to it above, was rather a funnel-like device and the reflection in the carapace of a filter feeding mechanism. Such a reconstruction would require modification of the anterior appendages to create a water current, presumably inhalent through the extremity of the "funnel" and exhalent through the ' $\mathrm{V}$ '-shaped incurvatures. It would also imply that the mandibles would be modified for filter feeding. This alternative mode of life would satisfy all the points raised in all the earlier discussions of gape, overlap, position of the adductor muscles and hinge.

We find it difficult to decide on the basis of a consideration of the unusual morphology of the genus, whether it was an active or passive feeder. Either mode seems equally possible. However, by analogy with other cyprid ostracods (although most available evidence is from freshwater rather than marine taxa) we feel obliged to favour the former.

There are, of course, other explanations. We are asked to believe that Archaeopteryx caught insects with the terminal feathers of its wings (Ostrom, 1974). Could Aratrocypris have caught its prey by "clapping" the baldes of its "plough" together in a similar fashion? Alternatively, perhaps the animal "clapped" its blades rapidly together to create a vigorous exhalent current of water to thrust the 

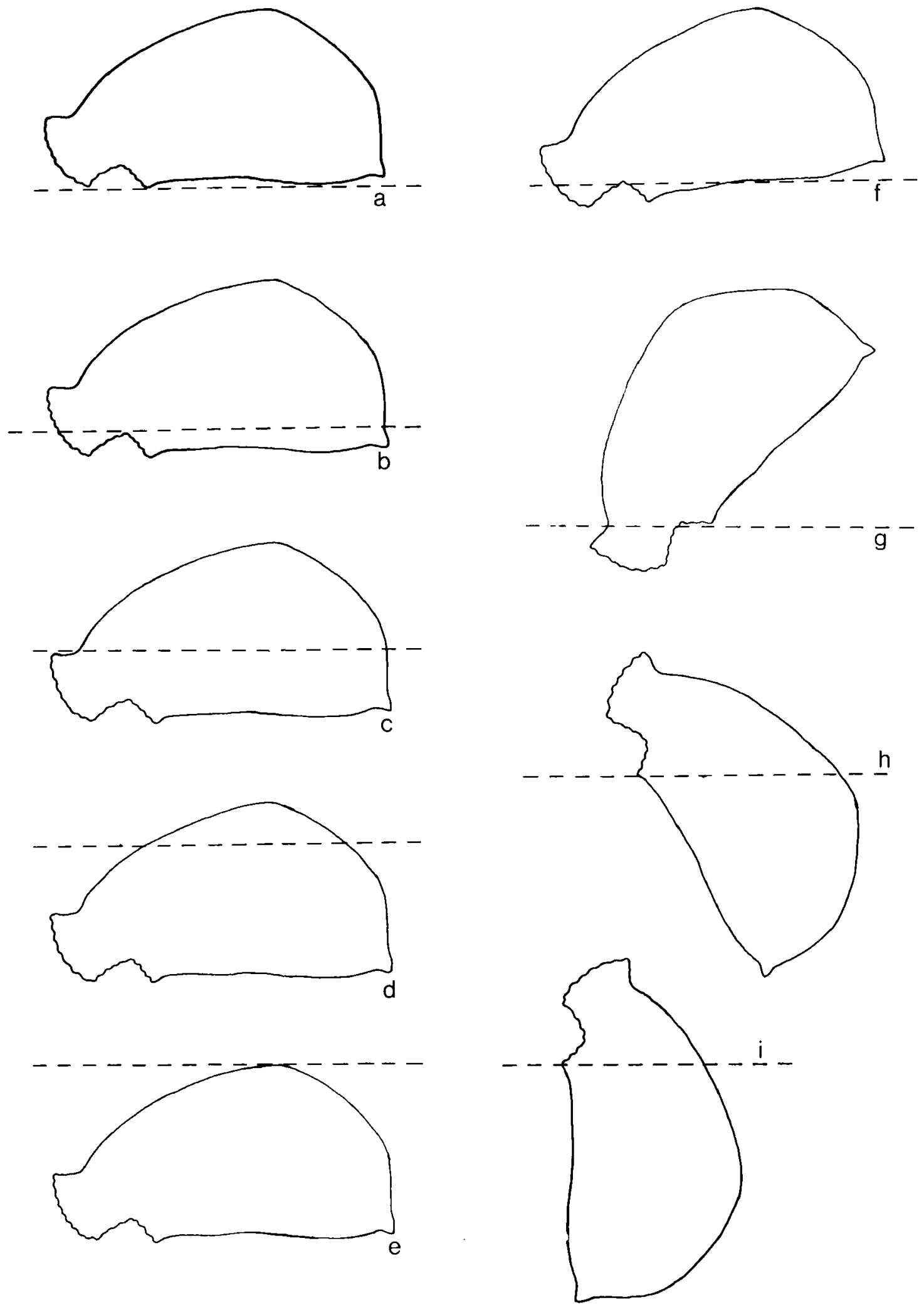

Fig. 2 Some possible life modes of Aratrocypris. 
animal backwards, in the way that scallops do. Could it be that the entire apparatus was evolved as an escape or even a normal propulsion mechanism?

In two species, Aratrocypris rectoporrecta and $A$. praealta, the two blades of the plough gape ventrally when the carapace is closed. A gape in this position is relatively rare in ostracods. A very similar gape is seen in the cytheracean paradoxostomatid genus Acetabulastoma Schornikov, 1970. This feature is well shown in Whatley, 1981 (pl. 2, figs. 7, 9, 12). In Acetabulastoma the gape is associated with the ectoparasitic mode of life of the genus; on the gills of amphipods.

Although the gape in the two species mentioned above is very similar to that found in Acetabulastoma it is not thought that Aratrocypris was parasitic or commensal in habit. The main argument against this is that neither A.vaccamaris nor $A$.sp. exhibit this structure. Also it is difficult to conceive of a host/parasite relationship which would have endured since the Palaeocene. The gape in $A$. rectoporrecta and $A$. praealta is, therefore, interpreted as being a particular refinement of the "plough" and associated with the postulated forward moving feeding habit suggested above.

Whatever the mode of life of Aratrocypris, it must have differed to a greater or lesser degree from that of any other ostracod, because no other taxa has ever evolved such a series of structures as those unique to this genus.

\section{ACKNOWLEDGEMENTS}

Harlow, Downing and Kesler wish to acknowledge N.E.R.C. for the studentships held by them during the course of this research. Christine Barnicoat typed the manuscript and Caroline Maybury assisted with S.E.M. photography. To them both we express our sincere thanks.

\section{REFERENCES}

Blow, W. N. 1969. Late Middle Eocene to Recent Planktonic foraminifera biostratigraphy. In Bronnimann, P. \& Renz, H. H. (Eds.), Proc. Int. Conf. Planktonic Microfossils 1 st. Geneva, 1967, 1, 199-421.

Cronin, T.M. 1983. Bathyal ostracodes from the Florida-Hattevas Slope, the Straits of Florida, and the Blake Plateau. Marine Micropalaeontology, 8 (1983/84), 89-119.

Maddocks, R. F. 1969. Recent Ostracodes of the Family Pontocyprididae. Chiefly from the Indian Ocean. Smithson. Contrib. Zool., No. 7, 55 pp.

McKenzie, K. G. 1967. Recent Ostracoda from Port Phillip Bay, Victoria. Proc. Roy. Soc. Victoria, 80(1), 61-106.

McKenzie, K. G. 1983. Chapman's "Mallee Bores" and "Sorrento Bore" Ostracoda in the National Museum of Victoria, with description of Maddocksella new genus. Proc. Roy. Soc. Vict., 94, 105-107.

Ostrom, J. H. 1974. Archaeopteryx and the origin of flight. Quart. Rev. Biol., 49, 27-47.

Whatley, R. C. 1981. Littoral and sub-littoral Ostracoda from Sisimuit, West Greenland. In Fox, A. D. \& Stroud, D. A. (Eds.) Report on the 1979 Greenland White-fronted Goose Study Expedition to Eqalungmint Nunal, West Greenland, 269-284, 2 pls.

Whatley, R. C. 1983. Some aspects of the palaeobiology of Tertiary deep-sea Ostracoda from the S.W. Pacific. J.micropalaeontol., 2, 83-104.

Whatley, R. C., Harlow, C. J., Downing, S. E. \& Kesler, K. J. 1984. Some observations on the origina, evolution, dispersion and ecology of the genera Poseidonamicus Benson and Bradleya Hornibrook. Proc 8th Int. Symposium Ostracoda, Houston, 1982, 473-492. 